\title{
Clinical biology and potential use of thrombopoietin
}

\author{
Russell Basser MBBS
}

R Basser. Clinical biology and potential use of thrombopoietin. Can J Gastroenterol 2000;14(Suppl D):73D-78D. The discovery of platelet growth factors raised expectations that an effective method for abrogating thrombocytopenia would soon be available in the clinic. The cytokines initially described were pleiotropic in nature, and stimulation of platelet production was generally modest. However, one of these agents, interleukin-11, was successfully shown to reduce the incidence of severe thrombocytopenia in patients receiving dose-intensive chemotherapy, and has now received approval from the United States Food and Drug Administration for this purpose. Initial clinical trials of thrombopoietin, the central regulator of megakaryocytopoiesis and thrombopoiesis, and its analogues showed these agents to be the most potent stimulators of thrombopoiesis and to be associated with few adverse effects. They have also been shown to enhance platelet recovery after chemotherapy, but early results from trials investigating their ability to prevent severe thrombocytopenia associated with the treatment of leukemia and bone marrow transplantation have been disappointing. In addition, subcutaneous administration of one of these agents, megakaryocyte growth and development factor, has been shown to induce the formation of antibodies that neutralize native thrombopoietin and cause thrombocytopenia. Platelet growth factors remain promising therapeutic agents; however, there are a number of obstacles to overcome before they find general use in the clinic.

Key Words: Clinical review; Megakaryocyte growth and development factor; Thrombopoietin

\section{Biologie clinique et usage potentiel de la thrombopoiétine}

RÉSUMÉ : La découverte des facteurs de croissance plaquettaire ont fait naître l'espoir de disposer éventuellement d'une méthode clinique efficace pour contrer la thrombocytopénie. Les premières cytokines découvertes étaient de nature pléiotropique et la stimulation de la production plaquettaire était en général modeste. Par contre, l'un des ces agents, l'interleukine-11, s'est révélé apte à réduire l'incidence de la thrombocytopénie grave chez les patients traités par chimiothérapie intensive et vient de recevoir l'approbation de la FDA pour cette indication. Les premiers essais cliniques sur la thrombopoiétine (TPO), principal régulateur de la mégacaryocytopoï̀se et de la thrombopoièse, et ses analogues ont révélé que ces agents sont de puissants stimulants de la thrombopoïèse et donnent lieu à peu de réactions indésirables. Ils ont également prouvé leur capacité de stimuler la remontée plaquettaire après la chimiothérapie, mais les résultats des premiers essais à avoir tenté de mesurer leur aptitude à prévenir la thrombocytopénie grave associée à la leucémie et à la transplantation de moelle osseuse ont été décevants. De plus, on a noté que l'administration sous-cutanée de l'un de ces agents, le facteur de croissance et de développement des mégacaryocytes, donnait lieu à la formation d'anticorps qui neutralisent la TPO native et causent la thrombocytopénie. Les facteurs de croissance plaquettaire sont sans contredit des agents thérapeutiques prometteurs, mais il reste plusieurs obstacles à surmonter avant qu'on puisse les utiliser d'emblée en clinique.
$\mathrm{B}$ efore the cytokine era, with no active means of manipulating blood counts, myelosuppression was managed conservatively. Patients were given red blood cell transfusions for anemia, antibiotics for neutropenic fever, and platelet transfusions for prophylaxis and treatment of bleeding. The clinical development of granulocyte colonystimulating factor (G-CSF) and granulocyte-macrophage colony-stimulating factor challenged this conservative ap- proach. The administration of these agents after chemotherapy was found to reduce the period of neutropenia, the frequency of fever and the duration of inpatient treatment, and to enhance the ability to maintain dose intensity (1). Furthermore, myeloid growth factors have been found to elevate neutrophil levels successfully in other causes of severe neutropenia, thereby reducing the frequency of infection (2-5).

When erythroid and myeloid growth factors were incor-

This mini-review was prepared from a presentation made at the World Congress of Gastroenterology, Vienna, Austria, September 6 to 11, 1998 Departments of Haematology and Medical Oncology, Royal Melbourne Hospital and Western Hospital, Victoria, Australia

Correspondence and reprints: Russel Basser, Departments of Haematology and Medical Oncology, Royal Melbourne Hospital, Parkville,

Victoria 3050, Australia. Telephone +61-3-9342-7695, fax +61-3-9347-7508, e mail russell.basser@mh.org.au

Received for publication February 11, 1999. Accepted February 25, 1999 


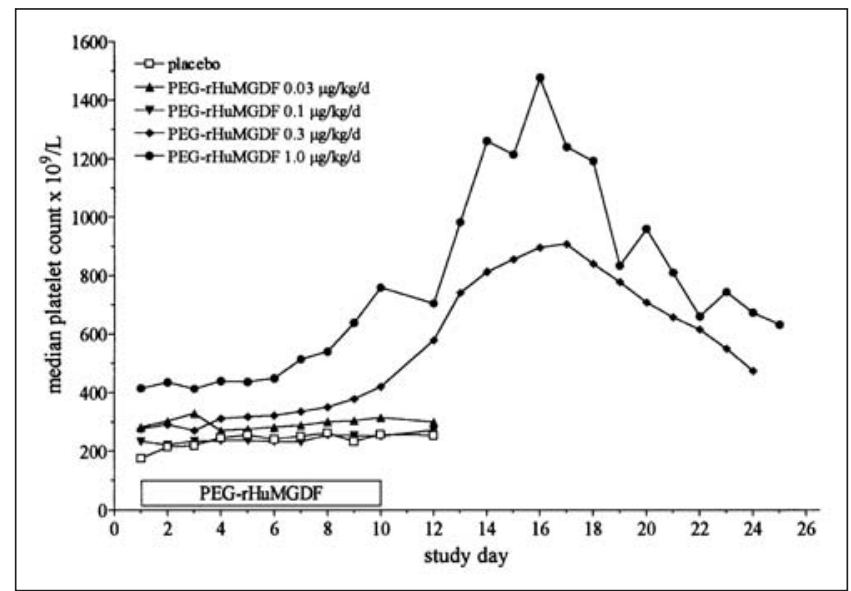

Figure 1) The effects of megakaryocyte growth and development factor (daily administration indicated by the bar) on platelet counts in patients receiving placebo, and $0.03,0.1,0.3$ and $1.0 \mu \mathrm{g} / \mathrm{kg} /$ day of pegylated recombinant human megakaryocyte growth and development factor (PEG-rHuMGDF). Reprinted with permission from reference 51

porated into clinical practice, there was great anticipation that it was only a matter of time until the discovery and clinical development of a thrombopoietic cytokine.

\section{THE SEARCH FOR THROMBOPOIETIN}

An adequate number of circulating blood platelets is vital to maintain hemostasis. The response to a reduction in platelet numbers is mediated through a complex and highly regulated process that involves the interaction of megakaryocytic progenitors, bone marrow stromal cells and cytokines (6). A number of cytokines, including interleukin (IL)-1 (7), IL-6 (8), IL-11 (9) and leukemia inhibitory factor (10), have been found to promote thrombopoiesis at different stages of progenitor cell and megakaryocyte development. However, the pleiotropic activities of these cytokines indicate that control of megakaryocytopoiesis is unlikely to be their primary physiological function.

The term thrombopoietin (TPO) was first coined in 1958, by Kelemen et al (11), to describe a humoral substance that appeared to regulate platelet production. Keleman et al (11) found that the urine, serum and plasma of animals and patients with severe thrombocytopenia could increase platelet numbers when injected into normal animals (12). However, the search for a single hormonal agent responsible for thrombopoiesis was so difficult that it was thought that this process might be controlled by a number of different cytokines.

The initial breakthrough in the search for TPO came with the discovery of the murine myeloproliferative oncogene, v-mpl (13). The great serendipity of this finding was realized with the recognition that the cellular homologue of $\mathrm{v}$-mpl, termed c-mpl, encoded the cytoplasmic portion of a membrane protein expressed on hematopoietic cells, predominantly those of megakaryocytic lineage $(14,15)$. A critical observation was that the addition of c-mpl antisense oligonucleotides to cultured CD34+ cells selectively pre- vented the generation of megakaryocyte colonies (15). The flurry of activity searching for the ligand to c-mpl came to a climax in 1994 with the publication of the sequence of the cDNA (16-21). Mpl ligand has subsequently been shown to be the central physiological regulator of megakaryocytopoiesis and platelet production, and is now referred to in its natural form as $\operatorname{TPO}(22,23)$.

Human TPO is a 60 to $70 \mathrm{kDa}$, glycosylated protein that is primarily produced in the liver and kidneys $(16,24)$. It consists of 332 amino acids, is highly conserved among species and has 23\% homology with human erythropoietin (EPO) (25). Recombinant human megakaryocyte growth and development factor (MGDF) is a truncated form of $\mathrm{Mpl}$ ligand with identical biological activity in vitro (26-28) and in vivo $(29,30)$. It is homologous with the EPO-like aminoterminus of human TPO $(16,27)$, suggesting that the EPOlike domain contains all the required elements to bind and activate c-mpl. The pegylated form of MGDF is approximately 10 times more potent in vivo than the nonpegylated molecule (31) and was chosen as the agent for clinical use by Amgen Inc (Australia). A full-length gycosylated form of TPO is being developed by Genentech Inc (California). Clinical trials with MGDF and TPO commenced in 1995.

\section{TPO - AT THE CENTRE OF PLATELET PRODUCTION}

TPO acts as a megakaryocyte growth and differentiation and/or maturation factor (26,32-37). The pivotal role of the cytokine in platelet production was demonstrated by the marked reduction in platelet levels in c-mpl- $(38,39)$ and TPO-deficient mice (40) to that of $5 \%$ to $15 \%$ of littermate controls. Because platelet counts in the deficient animals are detectable, it is obvious that other thrombopoietic cytokines such as IL-3, IL-6, IL-11 and stem cell factor play a minor role in platelet production.

Further evidence of the regulatory role of TPO in thrombopoiesis was demonstrated by the finding of an inverse relationship between platelet count and serum TPO in animals and humans (26,41-44). As platelet counts recovered, TPO levels decreased. Interestingly, production of TPO appears to be regulated by platelet mass, rather than at the transcriptional level (45-47), and it is unlikely that the rate of TPO gene expression is altered in response to physiological stimuli (22). Platelet c-mpl has a high affinity for the ligand $(48,49)$, and when bound, the ligand is internalized and degraded (50).

\section{CLINICAL STUDIES WITH TPO}

TPO alone: In a phase 1 study in patients with advanced cancer, a dose-dependent increase in platelet counts was observed after the administration of MGDF for up to 10 days (Figure 1), although considerable individual variation was seen in response (51). Patients who received 0.3 and $1.0 \mu \mathrm{g} / \mathrm{kg}$ MGDF had increases in platelet counts ranging from $51 \%$ to $584 \%$. Platelet counts peaked between days 12 and 18 inclusive, and they returned to normal between days 22 and 30. The delay between ceasing MGDF and the subse- 
quent maximum platelet count varied from two to 12 days. However, an increase in bone marrow megakaryocytes by up to 1.8 -fold was observed at doses of 0.03 to $1.0 \mu \mathrm{g} / \mathrm{kg} \mathrm{MGDF}$. The peak count was reached up to seven days after cessation of MGDF, and platelets returned to normal between days 22 and 30 . The rise in platelet counts in the lower dose cohorts was considerably less pronounced. No effects were observed on absolute neutrophil count or hematocrit.

These observations were consistent with those of Vadhan-Raj et al (52), who administered a single dose of TPO to patients before chemotherapy. They reported elevated platelet counts of up to $212 \%$, and the kinetics of thrombocytosis were similar to the results of the study by Basser et al (51).

TPO after chemotherapy: In an Australian study by Basser et al (53), MGDF 0.3 to $5.0 \mu \mathrm{g} / \mathrm{kg} /$ day was given with filgrastim following moderately myelosuppressive doses of chemotherapy (carboplatin $600 \mathrm{mg} / \mathrm{m}^{2}$ and cyclophosphamide $1200 \mathrm{mg} / \mathrm{m}^{2}$ ). The platelet nadir occurred significantly earlier than in the placebo group, analogous to the effect of $G$ CSF on neutrophil recovery following chemotherapy (53). However, MGDF did not influence the depth of the platelet nadir but shortened the time to recovery of pretreatment platelet count (median 17 days versus 22 days for the placebo group). In an American study by Fanucchi et al (54), when MGDF was given alone after paclitaxel $175 \mathrm{mg} / \mathrm{m}^{2}$ and carboplatin area under the curve (AUC) was 9, the nadir of the platelet count was higher and the time to recovery of baseline platelet count was shorter than that observed with placebo (55). No dose-response to MGDF was observed in this study. While this regimen only produced mild myelosuppression (nadir platelet count in the placebo group of $111 \times 10^{9} / \mathrm{L}$ ), the same investigators have reported preliminary results of a more intensive regimen in which patients were given the same dose of paclitaxel but with carboplatin AUC of 11 (55). The platelet nadir in the first cycle for the placebo plus MGDF $5 \mu \mathrm{g} / \mathrm{kg}$ group was $21 \times 10^{9} / \mathrm{L}$ and $89 \times 10^{9} / \mathrm{L}$, respectively. In addition, the number of patients requiring transfusion during the first two cycles was $64 \%$ and $17 \%$, respectively. In another meeting report, $\mathrm{MGDF}$ was shown to reduce platelet toxicity and transfusion requirements in patients receiving dose-intensive chemotherapy for nonHodgkin's lymphoma (56).

There is one published report on the effects of MGDF in the treatment of acute leukemia (57). No influence on the severity or duration of thrombocytopenia was demonstrated. TPO after high-dose chemotherapy: The only published reports of TPO after high-dose chemotherapy are in abstract form, but these provide an interesting insight into the difficulties that have emerged in the early clinical trials. In one study, 50 patients receiving high-dose chemotherapy and bone marrow support were given either placebo or MGDF, 5 or $10 \mu \mathrm{g} / \mathrm{kg}$ (58). Platelet recovery was improved in the MGDF groups, and was associated with a $34 \%$ reduction in the duration of severe thrombocytopenia and an almost 50\% reduction in the need for platelet transfusions. In contrast, MGDF did not improve platelet recovery after high-dose chemotherapy and peripheral blood progenitor cell (PBPC) support, when given either after (59), or before and after (60) progenitor transfusion. As mentioned above, the infusion of PBPC has been shown to enhance platelet recovery after high-dose chemotherapy compared with bone marrow, probably because of the greater number of stem cells that can be harvested. It may be that the use of PBPC has already reduced the duration of severe thrombocytopenia to an 'obligatory' minimum, and that further reduction with growth factors is not possible.

PBPC mobilization: Given the expression of c-mpl on CD34+ cells, the observations of progenitor cell mobilization in preclinical models, and the unexpected observations of PBPC mobilization during phase 1 studies of G-CSF, levels of PBPC were assessed in the early clinical trials of TPO.

In contrast to the lineage-restricted effect of MGDF on mature cells, mobilization of progenitor cells of all lineages occurred. However, there was a preferential increase in blood levels of megakaryocyte progenitor cells compared with myeloid progenitor cells and erythroid progenitor cells. The degree of mobilization appeared to be related to the dose of MGDF. An interesting observation was that the kinetics of progenitor cell release from the marrow were unlike that of other lineage-dominant cytokines, such as G-CSF. Following administration of G-CSF, PBPC levels rose almost immediately, peaked at day 5 or 6 and fell when G-CSF was ceased. However, MGDF resulted in a late and sustained rise in progenitor cells, so that increased levels were first detected only on day 8, after the first dose, and were generally greater on day 12 , despite discontinuation of the cytokine several days earlier. TPO has also been found to increase PBPC levels.

Administration of MGDF 0.3 to $5.0 \mu \mathrm{g} / \mathrm{kg}$ combined with filgrastim after chemotherapy significantly enhanced mobilization of PBPC compared with placebo plus filgrastim. Furthermore, higher peak levels of PBPC were observed with increasing doses of MGDF (53).

Platelet function: An increased sensitivty of platelets to aggregating agents by TPO has not been observed in clinical studies. There were no significant changes in aggregation response or ATP release between baseline measurements and repeated testing during and after TPO alone (52), or after MGDF when given alone (61) or with filgrastim after chemotherapy (53). Furthermore, there were no changes in coagulation parameters. The platelets produced by MGDF were morphologically normal by light and electron microscopy, and platelet activation markers did not change (61). In addition, in a patient who was given acetylsalicylic acid because of asymptomatic thrombocytosis due to MGDF (platelets peaking at $\left.1876 \times 10^{9} / \mathrm{L}\right)$, platelets responded with the expected inhibition of the aggregation response and ATP release (61).

Acute toxicity: Importantly, TPO has been associated with minimal acute toxicity. No constitutional symptoms nor changes in performance status, vital signs, body weight, or biochemical, renal or liver function tests have occurred in studies with MGDF $(53,54)$ or TPO $(52)$. Unlike other, less 
potent thrombopoietic cytokines, there was no evidence of induction of an acute phase response. A number of patients have been reported to develop very high platelet counts (greater than $1000 \times 10^{9} / \mathrm{L}$ ) without clinical sequelae. There were no significant differences in nonhematological toxicity between the groups who received pegylated recombinant human megakaryocyte growth and development factor compared with placebo. While thromboembolic events have been reported in patients receiving MGDF, the incidence appears to be no greater than that in patients given placebo and is consistent with the expected incidence in patients with advanced malignancy.

The observations of minimal toxicity and the lack of effect on function suggest that platelets produced in response to TPO or MGDF are more similar to normal platelets or those in patients with reactive thrombocytosis, than to the abnormal platelets in patients with a myeloproliferative disorder. In vitro abnormalities of platelet aggregation and clinical hemorrhagic and thrombotic events seldom occur in reactive thrombocytosis, but are quite common in patients with essential thrombocytosis $(62,63)$. In addition, a tendency toward thrombosis, in patients with thrombocytosis, is more closely linked to abnormalities in platelet function than to platelet count (64).

\section{FUTURE APPLICATIONS}

Early studies with MGDF and TPO suggested that these agents would find a role in a number of clinical situations. The most obvious are those in which severe thrombocytopenia and its consequences are a major cause of morbidity. These include the treatment of acute leukemia, stem cell transplantation, salvage therapy for lymphoma, bone marrow failure states, major surgery, liver disease and immune destruction of platelets. Early reports in acute leukemia and PBPC transplantation are disappointing $(57,65)$; however, these studies did not address the important issues of dose and schedule of a cytokine.

Inadequate TPO production has been shown to be at least partly responsible for the thrombocytopenia associated with cirrhosis $(66,67)$ and interferon treatment of chronic hepatitis C (68). The potent effect of TPO and MGDF on platelet production suggests that these molecules may prevent the complications of thrombocytopenia of chronic liver disease or facilitate the use of interferon in chronic viral hepatitis. However, no clinical reports of the use of TPO for these indications have been presented.

Because of its potency and apparent low level of toxicity, one of the most promising indications for TPO is in the treatment of platelet donors or patients with diseases associated with chronic thrombocytopenia. Use in platelet donors has the potential to enhance the efficiency of platelet collection and reduce the pool of donors required. Early trials of MGDF in platelet donors have been encouraging $(69,70)$, but recent reports of the development of neutralizing antibodies to TPO in patients receiving multiple injections of MGDF (55) have led to the abandonment of the development of this molecule. The appearance of antibodies has also been reported in patients given TPO, but the biological activity of antibodies in these studies is not known (52). These are intriguing observations, and similar incidents have not occurred following administration of other hematopoietic cytokines. The reason for the development of antibodies may partly lie in the long half-life of these molecules, which

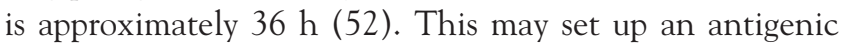
stimulus that results in antibody formation after multiple injections. The discovery of peptide agonists of $\mathrm{c}-m p l$ that are as potent as TPO in vitro (71) may pave the way for less immunogenic drugs to be developed.

\section{CONCLUSIONS}

The discovery of cytokines that stimulate platelet production and provide a means to protect against disease-related and treatment-induced thrombocytopenia is one of great promise. Indeed, the pace of clinical development of these agents is extraordinarily rapid. For instance, IL-11 was recently licensed for the secondary prevention of chemotherapy-induced thrombocytopenia only three years after the initial research application was submitted to the United States Food and Drug Administration. In addition, the clinical formulations of Mpl ligands entered clinical trials only nine months after the papers describing their discovery were published. However, the challenge of finding relevant clinical uses for thrombopoietic cytokines remains an important research priority for the future. The trials that resulted in the approval of IL-11 were ingenious in design but were performed in clinical scenarios for which there are few standard therapeutic equivalents. This is similar to the events that led to the approval of G-CSF, and later resulted in vigorous debate regarding the true value of G-CSF in prevention of neutropenia in standard cancer therapy. Clinical investigators and companies involved in trials of the thrombopoietic cytokines need to develop these valuable agents in a manner that maximizes their clinical value for the short and long term (72).

\section{REFERENCES}

1. Crawford J, Ozer H, Stoller R, et al. Reduction by granulocyte colony- stimulating factor of fever and neutropenia induced by chemotherapy in patients with small-cell lung cancer. N Engl J Med 1991;325:164-70.

2. Geller RB, Vogelsang GB, Wingard JR, et al. Successful marrow transplantation for acute myelocytic leukemia following therapy for Hodgkin's disease. J Clin Oncol 1988;6:1558-61.

3. Hammond WP, Price TH, Souza LM, Dale DC. Treatment of cyclic neutropenia with granulocyte colony-stimulating factor. N Engl J Med 1989;320:1306-11.

4. Jakubowski AA, Souza L, Kelly F, et al. Effects of human granulocyte colony-stimulating factor in a patient with idiopathic neutropenia. N Engl J Med 1989;320:38-42.

5. Muroi K, Ito M, Sasaki R, Suda T, Sakamoto S, Miura Y. Treatment of drug-induced agranulocytosis with granulocyte colony-stimulating factor. Lancet 1989;ii:55. (Lett)

6. Metcalf D. Hematopoietic regulators: Redundancy or subtlety? Blood 1993;82:3515-23.

7. Tewari A, Buhles WC, Starnes HF. Preliminary report: Effects of interleukin-1 on platelet counts. Lancet 1990;336:712-4.

8. Asano S, Okano A, Ozawa K, et al. In vivo effects of recombinant human interleukin-6 in primates: Stimulated production of platelets. Blood 1990;75:1602-5.

9. Du XX, Williams DA. Interleukin-11: A multifunctional growth factor derived from the hematopoietic microenvironment. Blood 1994;83:2023-30. 
10. Metcalf D, Hilton D, Nicola NA. Leukemia inhibitory factor can potentiate murine megakaryocyte production in vitro. Blood 1991;77:2150-3.

11. Kelemen E, Csehati I, Tanos B. Demonstration and some properties of human thrombopoietin in thrombcythemic sera. Acta Haematol 1958;20:350-5.

12. McDonald TP. Thrombopoietin: Its biology, purification, and characterization. Exp Hematol 1988;16:201-5.

13. Wendling F, Varlet P, Charon M, Tambourin P. MPLV: A retrovirus complex inducing an acute myeloproliferative leukemic disorder in adult mice. Virology 1986;149:242-6.

14. Souyri M, Vigon I, Penciolelli JF, Heard JM, Tambourin P, Wendling F. A putative truncated cytokine receptor gene transduced by the myeloproliferative leukemia virus immortalizes hematopoietic progenitors. Cell 1990;63:1137-47.

15. Methia N, Louache F, Vainchenker W, Wendling F. Oligodeoxynucleotides antisense to the protooncogene c-mpl specifically inhibit in vitro megakaryocytopoiesis. Blood 1993;82:1395-401.

16. Bartley TD, Bogenberger J, Hunt $\mathrm{P}$, et al. Identification and cloning of a megakaryocyte growth and development factor that is a ligand for the cytokine receptor Mpl. Cell 1994;77:1117-24.

17. de Sauvage FJ, Hass PE, Spencer SD, et al. Stimulation of megakaryopoiesis and thrombopoicsis by the c-Mpl ligand. Nature 1994;369:533-8.

18. Lok S, Kaushansky K, Holly RD, et al. Cloning and expression of murine thrombopoietin cDNA and stimulation of platelet production in vivo. Nature 1994;369:565-8.

19. Kato T, Ogami K, Shimada Y, et al. Purification and characterization of thrombopoietin. J Biochem (Tokyo) 1995;118:229-36.

20. Kuter DJ, Beeler DL, Rosenberg RD. The purification of megapoietin: A physiological regulator of megakaryocyte growth and platelet production. Proc Natl Acad Sci USA 1994;91:11104-8.

21. Wendling F, Maraskovsky E, Debili N, et al. cMpl ligand is a humoral regulator of megakaryopoiesis. Nature 1994;369:571-4.

22. Kaushansky K. Thrombopoietin: The primary regulator of platelet production. Blood 1995;86:419-31.

23. Kaushansky K. Thrombopoietin. N Engl J Med 1998;339:746-54.

24. Klein B, Zhang X-G, Lu ZY, Bataille R. Interleukin-6 in human multiple myeloma. Blood 1995;85:863-72.

25. Gurney AL, Kuang WJ, Xie MH, Malloy BE, Eaton DL, de Sauvage FJ. Genomic structure, chromosomal localization, and conserved alternative splice forms of thrombopoietin. Blood 1995;85:981-8.

26. Nichol JL, Hokom MM, Homkohl A, et al. Megakaryocyte growth and development factor. Analyses of in vitro effects on human megakaryopoiesis and endogenous serum levels during chemotherapyinduced thrombocytopenia. J Clin Invest 1995;95:2973-8.

27. Hunt P, Li YS, Nichol JL, et al. Purification and biologic characterization of plasma-derived megakaryocyte growth and development factor. Blood 1995;86:540-7.

28. Debili N, Wendling F, Katz A, et al. The Mpl-ligand or thrombopoietin or megakaryocyte growth and differentiative factor has both direct proliferative and differentiative activities on human megakaryocyte progenitors. Blood 1995;86:2516-25.

29. Ulich TR, Del Castillo J, Yin S, et al. Megakaryocyte growth and development factor ameliorates carboplatin-induced thrombocytopenia in mice. Blood 1995;86:971-6.

30. Harker LA, Hunt P, Marzec UM, et al. Regulation of platelet production and function by megakaryocyte growth and development factor in nonhuman primates. Blood 1996;87:1833-44.

31. Hokom MM, Lacey D, Kinstler OB, et al. Pegylated megakaryocyte growth and development factor abrogates the lethal thrombocytopenia associated with carboplatin and irradiation in mice. Blood 1995;86:4486-92.

32. Kaushansky K, Lok S, Holly RD, et al. Promotion of megakaryocyte progenitor expansion and differentiation by the c-Mpl ligand thrombopoietin. Nature 1994;369:568-71.

33. Zeigler FC, De Sauvage F, Widmer HR, et al. In vitro megakaryocytopoietic and thrombopoietic activity of c-mpl ligand (TPO) on purified murine hematopoietic stem cells. Blood 1994;84:4045-52.

34. Broudy VC, Lin NL, Kaushansky K. Thrombopoietin (c-mpl ligand) acts synergistically with erythropoietin, stem cell factor, and interleukin-11 to enhance murine megakaryocyte colony growth and increases megakaryocyte ploidy in vitro. Blood 1995;85:1719-26.
35. Banu N, Wang J, Deng B, Groopman JE, Avraham H. Modulation of megakaryocytopoiesis by thrombopoietin: The c-Mpl ligand. Blood 1995;86:1331-8.

36. Choi ES, Nichol JL, Hokom MM, HornKohl AC, Hunt P. Platelets generated in vitro from proplatelet-displaying human megakaryocytes are functional. Blood 1995;85:402-13.

37. Angchaisuksiri P, Carlson PL, Dessypris EN. Effects of recombinant human thrombopoietin on megakaryocyte colony formation and megakaryocyte ploidy by human CD34+ cells in a serum-free system. Br J Haematol 1996;93:13-7.

38. Gurney AL, Carver-Moore K, de Sauvage FJ, Moore MW. Thrombocytopenia in c-mpl-deficient mice. Science 1994;265:1445-7.

39. Alexander WS, Roberts AW, Nicola NA, Li R, Metcalf D. Deficiencies in progenitor cells of multiple hematopoietic lineages and defective megakaryocytopoiesis in mice lacking the thrombopoietic receptor c-Mpl. Blood 1996;87:2162-70.

40. de Sauvage FJ, Carver-Moore K, Luoh S-M, et al. Physiological regulation of early and late stages of megakaryocytopoiesis by thrombopoietin. J Exp Med 1996;183:651-6.

41. McCarty JM, Sprugel KH, Fox NE, Sabath DE, Kaushansky K. Murine thrombopoietin mRNA levels are modulated by platelet count. Blood 1995;86:3668-75.

42. Kuter DJ, Rosenberg RD. The reciprocal relationship of thrombopoietin (c-Mpl ligand) to changes in the platelet mass during busulfan-induced thrombocytopenia in the rabbit. Blood 1995;85:2720-30.

43. Meng YG, Martin TG, Peterson ML, Shuman MA, Cohen RL, Wong WL. Circulating thrombopoietin concentrations in thrombocytopenic patients, including cancer patients following chemotherapy, with or without peripheral blood progenitor cell transplantation. Br J Haematol 1996;95:535-41.

44. Emmons RV, Reid DM, Cohen RL, et al. Human thrombopoietin levels are high when thrombocytopenia is due to megakaryocyte deficiency and low when due to increased platelet destruction. Blood 1996;87:4068-71.

45. Stoffel R, Wiestner A, Skoda RC. Thrombopoietin in thrombocytopenic mice: Evidence against regulation at the mRNA level and for a direct regulatory role of platelets. Blood $1996 ; 87: 567-73$

46. Eaton DL, de Sauvage FJ. Thrombopoietin: the primary regulator of megakaryocytopoiesis and thrombopoiesis. Exp Hematol 1997;25:1-7.

47. Nagata Y, Shozaki Y, Nagahisa H, Nagasawa T, Abe T, Todokoro K. Serum thrombopoietin level is not regulated by transcription but by the total counts of both megakaryocytes and platelets during thrombocytopenia and thrombocytosis. Thromb Haemost 1997;77:808-14.

48. Fielder PJ, Gurney AL, Stefanich E, et al. Regulation of thrombopoietin levels by c-mpl-mediated binding to platelets. Blood 1996;87:2154-61.

49. Broudy VC, Lin NL, Sabath DF, Papayannopoulou T, Kaushansky K. Human platelets display high-affinity receptors for thrombopoietin. Blood 1997;89:1896-904.

50. Fielder PJ, Hass P, Nagel M, et al. Human platelets as a model for the binding and degradation of thrombopoietin. Blood 1997;89:2782-8.

51. Basser RL, Rasko JEJ, Clarke K, et al. Thrombopoietic effects of pegylated recombinant human megakaryocyte growth and development factor (PEG-rHuMGDF) in patients with advanced cancer. Lancet 1996;348:1279-81.

52. Vadhan-Raj S, Murray LJ, Bueso-Rarnos C, et al. Stimulation of megakaryocyte and platelet production by a single dose of recombinant human thrombopoietin in patients with cancer. Ann Intern Med 1997;126:673-81.

53. Basser RL, Rasko JE, Clarke K, et al. Randomized, blinded, placebo-controlled phase I trial of pegylated recombinant human megakaryocyte growth and development factor with filgrastim after dose-intensive chemotherapy in patients with advanced cancer. Blood 1997;89:3118-28.

54. Fanucchi M, Glaspy J, Crawford J, et al. Effects of polyethylene glycol-conjugated recombinant human megakaryocyte growth and development factor on platelet counts after chemotherapy for lung cancer. N Engl J Med 1997;336:404-9.

55. Crawford J, Glaspy J, Belani C, et al. A randomized, placebo-controlled, blinded, dose scheduling trial of pegylated recombinant human megakaryocyte growth and development factor (PEG-rHuMGDF) with filgrastim support in non-small cell lung cancer (NSCLC) patients treated with paclitaxel and carboplatin 
during multiple cycles of chemotherapy. Proc Am Soc Clin Oncol 1998;17:73A. (Abst)

56. Moskowitz C, Nimer S, Gabrilove J, et al. A randomized, double-blind, placebo-controlled, dose-finding, efficacy and safety study of PEG-rHuMGDF (M) in non-Hodgkin's lymphoma (NHL) patients (pts) treated with ICE (ifosfamide, carboplatin and etoposide). Proc Am Soc Clin Oncol 1998;17:76A. (Abst)

57. Archimbaud E, Ottman O, Liu Yin JA, et al. A randomized, double-blind, placebo-controlled study using PEG-rHuMGDF as an adjunct to chemotherapy for adults with denovo acute myeloid leukaemia: early results. Blood 1996;88(Suppl 1):447A. (Abst)

58. Beveridge R, Schuster M, Waller E, et al. Randomized, double-blind, placebo-controlled trial of pegylated recombinant human growth and development factor (PEG-rHUMGDF) in breast cancer patients (Pts) following autologous bone marrow transplantation (ABMT). Blood 1997;90(Suppl 1):580A. (Abst)

59. Bolwell B, Vredenburgh J, Overmoyer B, et al. Safety and biologic effect of pegylated recombinant human megakaryocyte growth and development factor (PEG-rHuMGDF) in breast cancer patients following autologous peripheral blood progenitor cell transplantation (PBPC). Blood 1997;90(Suppl 1):171A. (Abst)

60. Glaspy J, Vredenburgh J, Demetri GD, et al. Effects of pegylated recombinant human megakaryocyte growth and development factor (PEG-rHuMGDF) before high-dose chemotherapy (HDC) with peripheral blood progenitor cell (PBPC) support. Blood 1997;90(Suppl 1):580A. (Abst)

61. O'Malley CJ, Rasko JE, Basser RL, et al. Administration of pegylated recombinant human megakaryocyte growth and development factor to humans stimulates the production of functional platelets that show no evidence of in vivo activation. Blood 1996;88:3288-98.

62. Ginsburg AD. Platelet function in patients with high platelet counts. Ann Intern Med 1975;82:506-11.

63. Buss DH, Cashell AW, O'Connor ML, Richards F, Case LD.
Occurrence, etiology, and clinical significance of extreme thrombocytosis: A study of 280 cases. Am J Med 1994;96:247-53.

64. Wu KK. Platelet hyperaggregability and thrombosis in patients with thrombocythemia. Ann Intern Med 1978;88:7-11.

65. Wolff S, Lynch J, Herzig R, et al. Safety and activity of recombinant human thrombopoietin (rhTPO) in patients (pts) receiving autologous bone marrow transplant (ABMT): Preliminary results of a phase I/II trial. Proc Am Soc Clin Oncol 1997;16:109A. (Abst)

66. Martin TG, Somberg KA, Meng YG, et al. Thrombopoietin levels in patients with cirrhosis before and after orthotopic liver transplantation. Ann Intern Med 1997;127:285-8.

67. Peck-Radosavljevic M, Zacherl J, Meng YG, et al. Is inadequate thrombopoietin production a major cause of thrombocytopenia in cirrhosis of the liver? J Hepatol 1997;27:127-31.

68. Peck-Radosavljevic M, Wichlas M, Pidlich J, et al. Blunted thrombopoietin response to interferon alfa-induced thrombocytopenia during treatment for hepatitis C. Hepatology 1998;28:1424-9.

69. Kuter D, McCullough J, Romo J, et al. Treatment of platelet (PLT) donors with pegylated recombinant human megakaryocyte growth and development factor (PEG-rHuMGDF) increases circulating PLT counts (CTS) and PLT apheresis yields and increases platelet incremements in recipients of PLT transfusions. Blood 1997;90(Suppl 1):579A. (Abst)

70. Harker LA, Carter RA, Marzec UM, et al. Effects of bolus PEG-rHuMGDF on platelet production, function and lifespan in normal human volunteers. Blood 1998;92(Suppl 1):31A. (Abst)

71. Cwirla SE, Balasubramanian P, Duffin DJ, et al. Peptide agonist of the thrombopoietin receptor as potent as the natural cytokine. Science 1997;276:1696-9.

72. Phillips KA, Tannock IF. Design and interpretation of clinical trials that evaluate agents that may offer protection from the toxic effects of cancer chemotherapy. J Clin Oncol 1998;16:3179-90. 


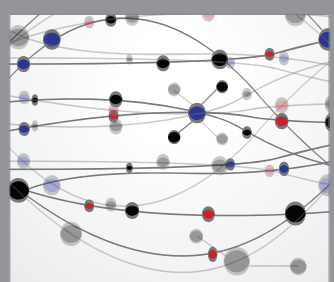

The Scientific World Journal
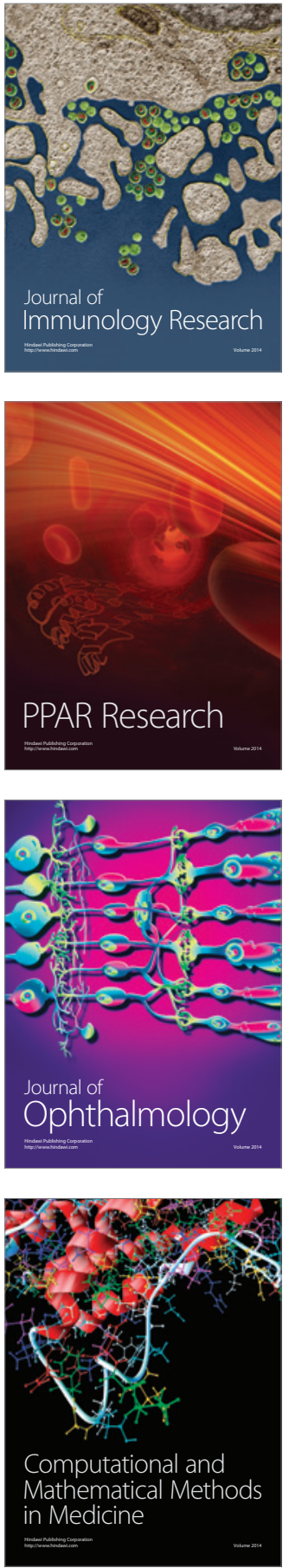

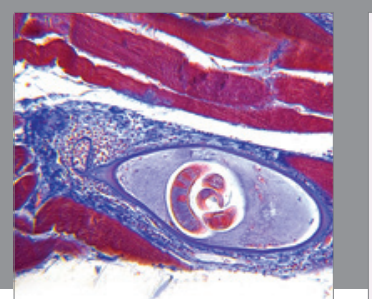

Gastroenterology Research and Practice

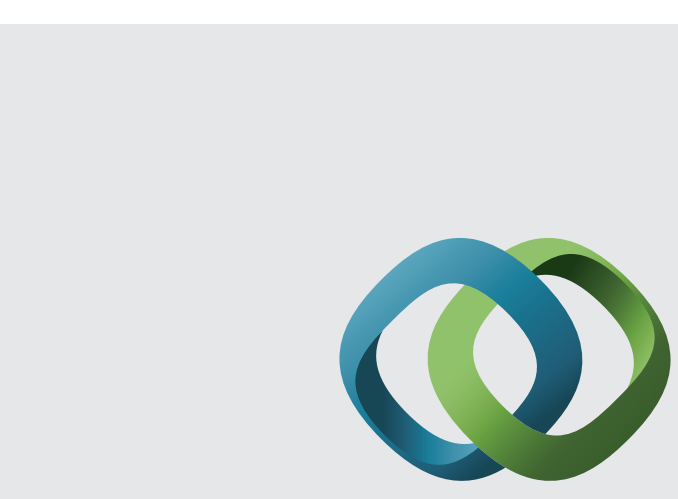

\section{Hindawi}

Submit your manuscripts at

http://www.hindawi.com
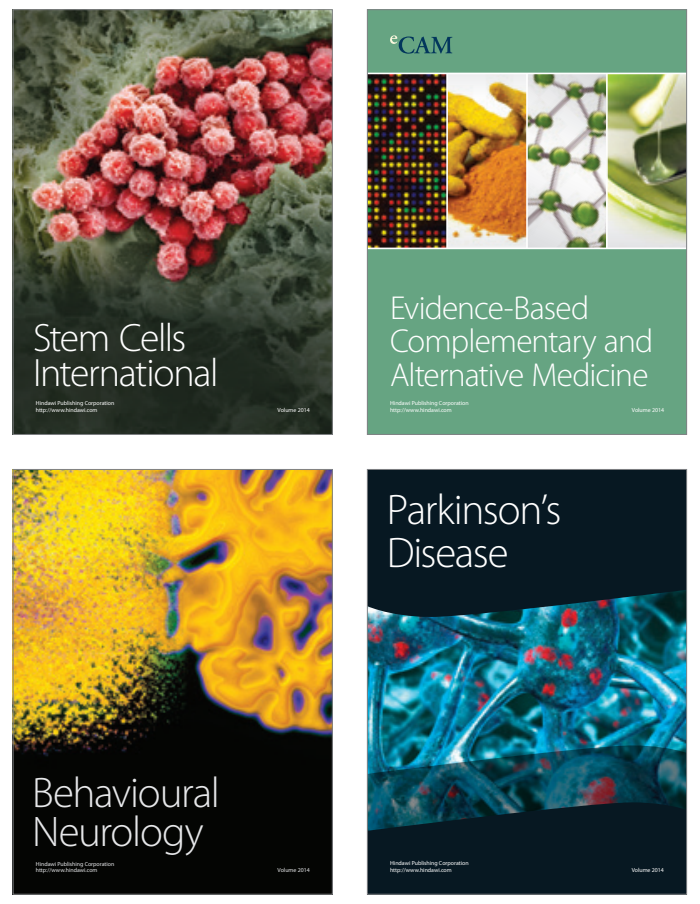
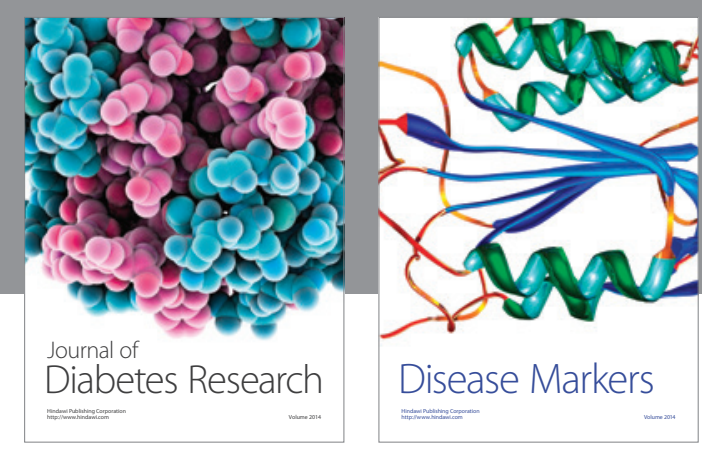

Disease Markers
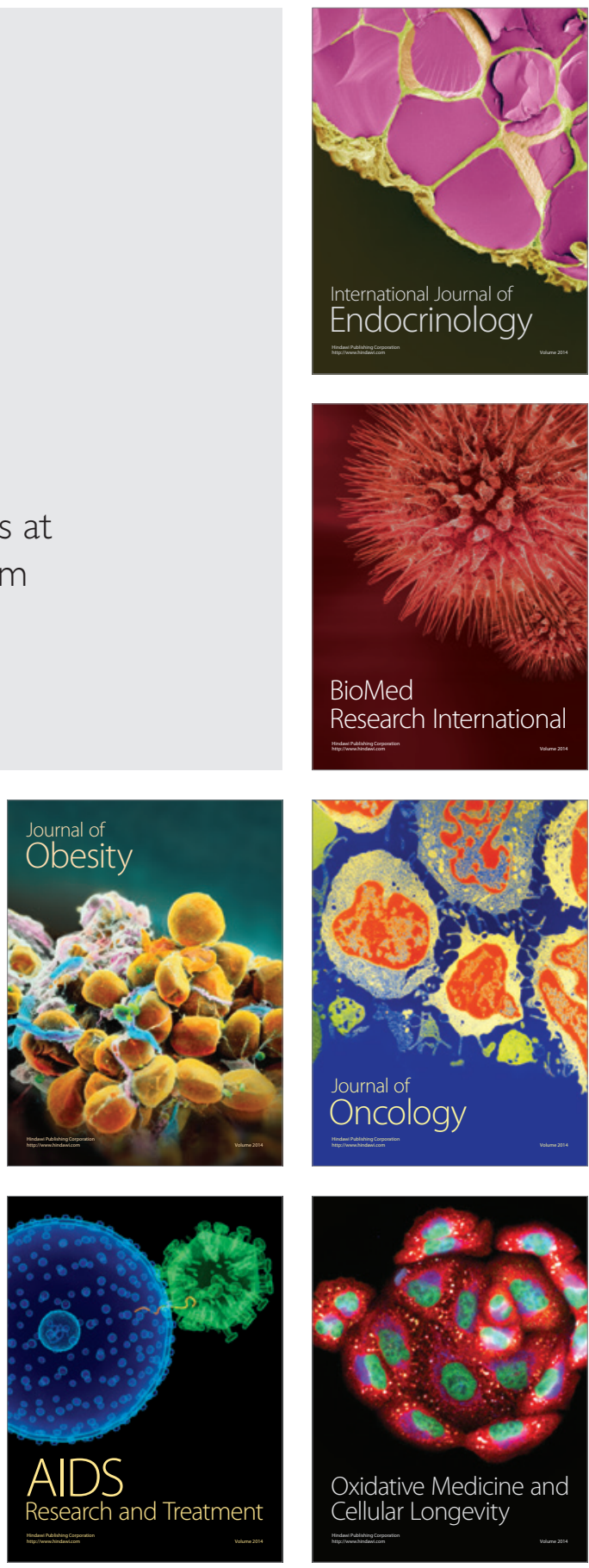